\title{
Analysis of Growth Parameters for Crop Vegetables under Broad and Narrow LED Spectra and Fluorescent Light Tubes at Different PPFs
}

\author{
Augusto Peixe ${ }^{1,2}$, Hugo Ribeiro ${ }^{2}$, Augusto Ribeiro ${ }^{2}$, Marco Soares ${ }^{3}$, Rui Machado ${ }^{1,2}$, Ana E. Rato ${ }^{1,2}$ \& Renato \\ Coelho ${ }^{1,4}$ \\ ${ }^{1}$ ICAAM/IIFA, Universidade de Évora/ECT, Ap. 94, 7002-554 Évora, Portugal \\ ${ }^{2}$ Universidade de Évora, Departamento de Fitotecnia, Ap. 94, 7002-554 Évora, Portugal \\ ${ }^{3}$ Aralab L La., R. Orfanato Escola Santa Isabel 3, 2635-047 Rio de Mouro, Portugal \\ ${ }^{4}$ Universidade de Évora, Departamento de Biologia, Ap. 94, 7002-554 Évora, Portugal \\ Correspondence: Augusto Peixe, Universidade de Évora - Departamento de Fitotecnia, Ap. 94, 7002-554 Évora, \\ Portugal. E-mail: apeixe@uevora.pt
}

Received: November 4, 2017

Accepted: December 1, 2017

Online Published: February 23, 2018

doi: 10.5539/jps.v7n1p47

URL: https://doi.org/10.5539/jps.v7n1p47

\begin{abstract}
Several physiological and yield parameters were evaluated in lettuce plants, cv. 'Trocadero', while growing at four different photosynthetic photon flux (PPF) $\left(70,120,250\right.$ and $\left.400 \pm 10 \mu \mathrm{mol} \mathrm{m}^{-2} \mathrm{~s}^{-1}\right)$, under four light spectra, white $(\mathrm{W})$, red (R) and blue (B) Light-Emitting Diode (LED) lamps and cool white fluorescent tubes (FL). Yield parameters were also evaluated on spinach, turnip and radish, growing under identical light spectra but using a single PPF $\left(340 \pm 10 \mu \mathrm{mol} \mathrm{m}^{-2} \mathrm{~s}^{-1}\right)$. Lettuce development was impaired at PPFs below $250 \mu \mathrm{mol} \mathrm{m} \mathrm{m}^{-2} \mathrm{~s}^{-1}$ for all tested spectra. At higher PPFs ( 250 and $400 \pm 10 \mu \mathrm{mol} \mathrm{m}^{-2} \mathrm{~s}^{-1}$ ), for the two broad spectra tested (W LEDs and FL light), no significant differences were registered on all physiological and yield parameters evaluated. On all situations W LEDs performed, at least, as good as the FL light, indicating that actual W LEDs can efficiently replace traditional light sources, with all the inherent benefits, which include significant lower power consumption. For all species, narrow light spectra (R and B LEDs) proved not being able to provide normal plant development. Plants under R LEDs, although presenting, in some situations, a fresh weight higher than those achieved with the broad light spectra, always led to abnormal plant morphology, characterized by expanded petioles and leaf curling. B LEDs, in spite of promoting plant growth with normal morphology, frequently led to a lower number of leaves and consequently to a lower fresh weight.
\end{abstract}

Keywords: controlled environment, light intensity, light spectra, photosynthesis, plant growth, yield parameters

\section{Introduction}

LED light is known since 1920, however, a practical visible-light version (red), usable only as indicator lamps due to its very low power, was only developed in the early 1960s. Through the 70s, new technical developments were achieved, and lamps operated in short wavelength ranges (orange, yellow, and green) were released. The first blue LED lamp was developed in 1993 and, in 1996, a phosphor coating was applied to a blue LED to create the world's first white LED lamp (Bourget, 2008). The major advance in LED technology was the development of the first high-power (1 W or greater) lamp device, in 1999, and, in the first years of this century, LED light efficiency rapidly overcome the majority of light sources available until then, becoming as efficient as the sodium vapour lamps (Pimputkar, Speck, DenBaars \& Nakamura, 2009).

As stated by Brandon et al. (2016), LED light present several advantages when compared with traditional light sources; - Lower consumption and longer lamp life; - Light intensity adjustment 0-100\% (dimming); - Lower heat emission, allowing its installation near the plant canopy. The knowledge of these advantages, combined with the possibility of using specific wavelengths, have driven the interest of plant producers on the use of LED light, either as a supplement, in conditions where the natural light is not enough, or for plant production under $100 \%$ artificial light conditions.

Having the tools to build a customized light spectrum, it was the time for researchers to look for the best spectral composition which could maximize plant development and production. The need to use red light to power up photosynthesis was widely accepted for two reasons. First, due to the McCree curves (Mc Cree, 1971), which 
indicate that wavelengths within the range of 600 to $700 \mathrm{~nm}$ are more efficiently absorbed by plant pigments, and second, because the first available LEDs were red, emitting at $660 \mathrm{~nm}$, close to one of the absorption peaks of chlorophyll. Another wavelength, within the range of $400 \mathrm{to} 500 \mathrm{~nm}$, corresponding to the blue region of the visible spectrum, was also included in the early studies (Massa, Kim, Wheeler \& Mitchell, 2008). Blue light is linked to several important photomorphogenic responses in plants, including stomatal control, which affects water relations and $\mathrm{CO}_{2}$ exchange (Schwartz \& Zeiger, 1984), stem elongation (Cosgrove, 1981) and phototropism (Blaauw \& Blaauw-Jansen, 1970).

Studies looking for the best combination of red and blue LEDs, able to optimize plant growth in controlled environments, were done on lettuce by Okamoto, Yanagi and Kondo (1997), Yorio, Goins, Kagie, Wheeler and Sager (2001), Johkan, Shoji, Goto, Hashida, and Yoshihara (2010), Lin et al. (2013) and Borowski, Michalek, Rubinowska, Hawrylak-Nowak and Grudzinski (2015), as well as on other plant species, such as: Lilium (Lian, Murthy \& Paek, 2002), Chrysanthemum sp. (Kim, Goins, Wheeler \& Sager, 2004), Withania somnifera (Lee, Tewari, Hahn \& Paek, 2007), Doritaenopsis (Shin, Murthy, Heo, Hahn \& Peak, 2008), Brassica rapa subsp. chinensis (Li, Tang, Xu, Liu \& Han, 2012), Valerianella locusta (Wojciechowska, Kołton, Długosz-Grochowska, Żupnik \& Grzesiak, 2013). However, as stated by Mitchell (2015), growing plants under red light and then conclude that adding a little blue light makes them grow even better, is not surprising. In fact, if a little green light is added along with red and blue, plant species with some mutual leaf shading grow even better (Kim et al., 2004; Lu et al., 2012). Adding some Far-Red light (FR) plants grow taller (Brown, Schuerger \& Sage, 1995; Chia \& Kubota, 2010); and some photoperiodic classes of plants flower better when this light wavelength is present during night-break lighting (Deitzer, Hayes \& Jabben, 1979; Kohyama, Whitman \& Runkle, 2014). Some species develop physiological disorders like gall-like tumours on their leaves and shoot tips, generally due to a deficiency of ultraviolet radiation (Morrow \& Tibbitts, 1988). Ultraviolet light also promotes biosynthesis of pigments and accumulation of a wide array of phytochemicals in fruits and vegetables (Li \& Kubota, 2009; Samuoliené et al., 2013).

So, will we eventually need for artificial light to have a broad spectrum similar to that of the sun for maximum yield and quality? Are we gradually rediscovering the value of white light for growing plants? On such scenario, can the white LEDs be the answer?

White LEDs are mostly produced by using blue LEDs and phosphors coated caps. In the first years of this century, the efficiency of blue LEDs ( 3 to $4 \%$ ) was low when compared with the efficiency of red LEDs (15-18\%) (Massa, Emmerich, Morrow, Bourget \& Mitchell, 2006). Since then, the efficiency of blue LEDs has dramatically increased, which has made possible to significantly improve white LEDs performance (Pimputkar et al., 2009). New developments also arose on white LED light production. Improvements on the efficiency of green LEDs, allowed higher performance of systems based on mixtures of red, blue and green emitting diodes. The use of purple emitting diodes, coated by a new recently-developed phosphor mixture (TRI-R white LED technology developed by Toshiba), allowed the production of white light with a spectrum closer to sunlight. The actual efficiency of LEDs is around $66 \%$ for blue, $44 \%$ for red and $33 \%$ for white based on blue phosphor-converted LED, having the last one significant margin for further improvement. In fact, an efficiency of $61 \%$, is considered to be the upper phosphor-converted white LEDs potential.

Regardless of the way LED white-light is produced, the main limitation, its low efficiency, has been overcome. On such circumstances, is it possible for the new white LEDs to replace traditional light sources, such as fluorescent lamps, in production systems using $100 \%$ artificial light for plant growth?

In this research, two trials were conducted to evaluate the efficiency of narrow and broad band LED spectra on the development of several horticultural species. Traditional cool white fluorescent lamps were used as control.

\section{Method}

\subsection{Plant Material and Growth Conditions}

Seeds of Lactuca sativa L. cv. 'Trocadero', Spinacia oleracea L cv. 'Gigante de Inverno', Brassica rapa L. var. rapa cv. 'Bola de Neve' and Raphanus sativus L. cv. 'Redondo Vermelho', were used. The seeds were germinated on a plant growth chamber (15000EDTU from Aralab ${ }^{\circledR}$, Portugal) in 84-cell plug trays filled with vermiculite (one seed/cell), under a $16 \mathrm{~h}$ photoperiod, a PPF of $200 \pm 10 \mu \mathrm{mol} \mathrm{m}^{-2} \mathrm{~s}^{-1}, 22 / 20{ }^{\circ} \mathrm{C}$ day/night temperature and $70 \%$ relative humidity.

In the lettuce trial, seedlings at the 4 to 6 leaf stage were transferred to individual pots $(0,60 \mathrm{~L})$ filled with perlite and maintained under the growth conditions previously described. Seven days later, 256 plants, as homogeneous as possible, were selected and transferred to 16 light treatments, with four PPF intensities and four different light 
sources (Figure 1) (see 2.3. for details). For the trial with spinach, turnip and radish, 64 seedlings per specie were selected and submitted to the same 4 light treatments used in the trial with lettuce but established under a single PPF.

PPF was measured using a quantum sensor (SKP200 from Skye Instruments, UK) and the light spectral distribution was evaluated using a spectroradiometer USB2000+ Ocean Optics FL, USA.
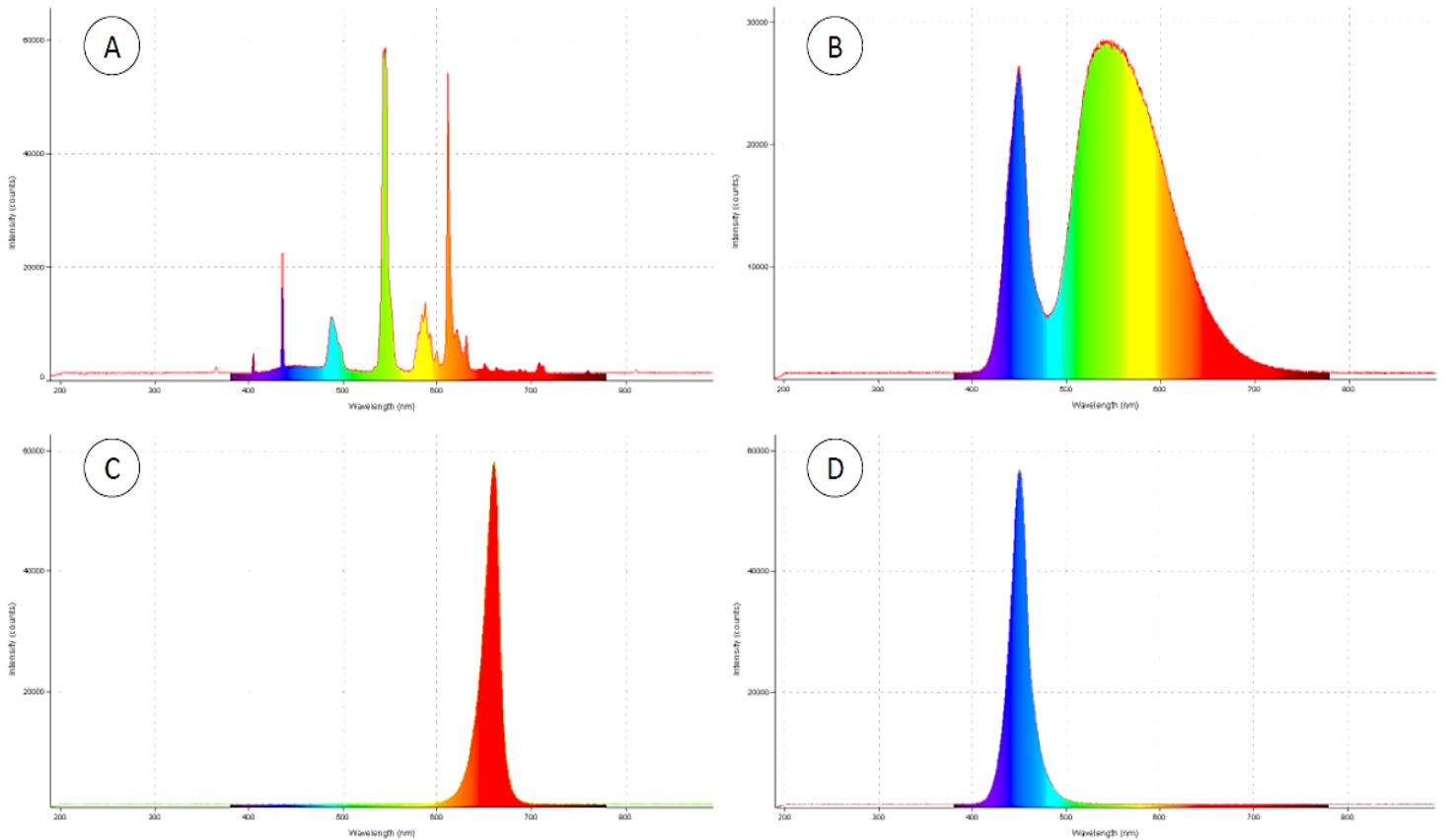

Figure 1. Spectral photon distributions of the four light treatments. (A) Fluorescent tubes; (B) White LEDs; (C) Red LEDs, (D) Blue LEDs

Plants were irrigated twice a day with a nutrient solution containing $5 \mathrm{mmol} \cdot \mathrm{L}^{-1} \mathrm{NO}_{3}, 1.8 \mathrm{mmol} \cdot \mathrm{L}^{-1} \mathrm{NH}_{4}, 0.45$ $\mathrm{mmol} \cdot \mathrm{L}^{-1} \mathrm{P}, 3.90 \mathrm{mmol} \cdot \mathrm{L}^{-1} \mathrm{~K}, 1.2 \mathrm{mmol} \cdot \mathrm{L}^{-1} \mathrm{Ca}, 0.49 \mathrm{mmol} \cdot \mathrm{L}^{-1} \mathrm{Mg}, 0.33 \mathrm{mmol} \cdot \mathrm{L}^{-1} \mathrm{~S}, 46 \mu \mathrm{mol} \cdot \mathrm{L}^{-1} \mathrm{~B} ; 7.86 \mu \mathrm{mol} \cdot \mathrm{L}^{-}$ ${ }^{1} \mathrm{Cu}, 8.95 \mu \mathrm{mol} \cdot \mathrm{L}^{-1} \mathrm{Fe}, 18.3 \mu \mathrm{mol} \cdot \mathrm{L}^{-1} \mathrm{Mn}, 1 \mu \mathrm{mol} \cdot \mathrm{L}^{-1} \mathrm{Mo}$, and $2 \mu \mathrm{mol} \cdot \mathrm{L}^{-1} \mathrm{Zn}, 1.8 \mathrm{mmol} \cdot \mathrm{L}^{-1} \mathrm{Cl}$ and $0.5 \mathrm{mmol} \cdot \mathrm{L}^{-}$ ${ }^{1} \mathrm{Na}$.

Environmental conditions provided by growth chambers Fitoclima1200PLH, from Aralab ${ }^{\circledR}$ (Portugal), were maintained with $12 \mathrm{~h}$ photoperiod, $22{ }^{\circ} \mathrm{C} / 14{ }^{\circ} \mathrm{C}$ (day/night) temperature and $65 / 80 \%$ (day/night) relative humidity.

\subsection{Plant Measurements}

The physiological parameters, photosynthetic rate $(A)$, stomatal conductance $\left(g_{s}\right)$, maximum quantum efficiency of PSII photochemistry $(\mathrm{Fv} / \mathrm{Fm})$ and relative chlorophyll $(\mathrm{Chl})$ content, were measured only in the trial with lettuce.

Relative chlorophyll content was measured using a chlorophyll content meter CL-01 from Hansatech Instruments (UK), while chlorophyll fluorescence analysis of maximum quantum efficiency of PSII photochemistry was measured using a chlorophyll fluorometer OS-30p+ from Opti-Sciences (USA). Leaves were allowed to darkadapt for $30 \mathrm{~min}$ before measurement.

Stomatal conductance measurements were taken with porometer AP4 from Delta-T (UK) between 9:30 and 12:30 AM on two of the youngest fully expanded leaves per plant.

Gas exchange measurements were carried out with an LCi Portable Photosynthesis System from ADC BioScientific Ltd. (UK). Measurements were conducted on completely expanded mid-leaf blades.

Analysis of yield parameters included leaf number, shoot and root fresh and dry weights (fresh weight was evaluated only in the trial with lettuce), being the dry weights of leaf and root measured after oven-drying at $80^{\circ} \mathrm{C}$ for $96 \mathrm{~h}$. 


\subsection{Experimental Design and Statistical Analysis}

The trial with lettuce was conducted with four PPF intensities, 70, 120, 250 and $400 \pm 10 \mu \mathrm{mol} \mathrm{m}^{-2} \mathrm{~s}^{-1}$ and four different light spectra provided by cool white fluorescent lamps (Fl) (Philips Master PL-L 55W/840/4P), that were used as control and White (W), Red (R) or Blue (B) LEDs, provided by Philips Green Power Led Research modules. The same light spectra were used in the trial with spinach, turnip and radish, which was established using a single PPF of $340 \pm 10 \mu \mathrm{mol} \mathrm{m}^{-2} \mathrm{~s}^{-1}$. Sixteen plants were used on each PPF/Light Source combination. All trials were conducted at the University of Évora, Portugal.

Physiological parameters were determined only on lettuce, 35 days after seedlings were submitted to light treatments. Plants from both trials were harvested at day 40 for assessment of yield parameters.

All the collected data were submitted to ANOVA analyses followed by post-hoc evaluation using the Tukey test, being significant differences considered at $p \leq 0.05$. The STATISTICA Version 10 software (Statistica, Tulsa, USA) was used for data analysis.

\section{Results}

\subsection{Analysis of Yield Parameters}

\subsubsection{Trial with Lettuce under Four Light Intensities and Four Light Spectra}

From the results of yield parameters presented in table 1, it is possible to observe that PPF significantly affected all variables under evaluation, being the best values achieved when the highest PPFs ( 250 and $400 \mu \mathrm{mol} \mathrm{m}^{-2} \mathrm{~s}^{-1}$ ) were used. This is particularly evident for the total dry weight and for the root fresh weigh, but it is also a general tendency for all the other variables. By increasing PPF from 250 to $400 \mu \mathrm{mol} \mathrm{m}^{-2} \mathrm{~s}^{-1}$, no increase in the total dry weight was registered, and, a significant reduction on the total fresh weight was observed, especially when the narrow spectra ( $\mathrm{R}$ and B LEDs) were used. This may be related with the saturation of photoreceptors for specific wavelengths, but can also be due to inefficient water and nutrient supply, situations that will be discussed further.

Table 1. Yield parameters for Lactuca sativa cv. 'Trocadero'

\begin{tabular}{|c|c|c|c|c|c|c|c|c|}
\hline 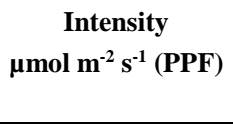 & $\begin{array}{c}\text { Light } \\
\text { spectra }\end{array}$ & $\begin{array}{c}\text { Leaf } \\
\text { number/plant } \\
\text { (n) } \\
\end{array}$ & $\begin{array}{c}\text { Shoot fresh } \\
\text { weight } \\
\text { (g/plant) } \\
\end{array}$ & $\begin{array}{c}\text { Shoot dry } \\
\text { weight } \\
\text { (g/plant) }\end{array}$ & $\begin{array}{c}\text { Root fresh weigh } \\
\text { (g/plant) }\end{array}$ & $\begin{array}{c}\text { Root dry } \\
\text { weight } \\
\text { (g/plant) }\end{array}$ & $\begin{array}{c}\text { Total fresh } \\
\text { weight } \\
\text { (g/plant) } \\
\end{array}$ & $\begin{array}{c}\text { Total dry } \\
\text { weight } \\
\text { (g/plant) }\end{array}$ \\
\hline \multirow{4}{*}{70} & (Fl) & $28 \mathrm{de}$ & $24.1 \mathrm{~g}$ & $1.33 \mathrm{c}$ & $2.26 \mathrm{~b}$ & $0.13 \mathrm{~d}$ & $26.3 \mathrm{f}$ & $1.46 \mathrm{~b}$ \\
\hline & (W) & $29 \mathrm{~d}$ & $29.1 \mathrm{fg}$ & $1.47 \mathrm{c}$ & $2.42 \mathrm{~b}$ & $0.15 \mathrm{~d}$ & $31.5 \mathrm{f}$ & $1.62 \mathrm{~b}$ \\
\hline & (R) & $26 \mathrm{de}$ & $25.2 \mathrm{~g}$ & $1.19 \mathrm{c}$ & $1.50 \mathrm{~b}$ & $0.11 \mathrm{~d}$ & $26.7 \mathrm{f}$ & $1.30 \mathrm{~b}$ \\
\hline & (B) & $18 \mathrm{~g}$ & $22.1 \mathrm{~g}$ & $1.34 \mathrm{c}$ & $2.60 \mathrm{~b}$ & $0.14 \mathrm{~d}$ & $24.7 \mathrm{f}$ & $1.48 \mathrm{~b}$ \\
\hline \multirow{4}{*}{120} & (Fl) & $26 \mathrm{de}$ & $24.9 \mathrm{~g}$ & $1.61 \mathrm{c}$ & $2.86 \mathrm{~b}$ & $0.15 \mathrm{~d}$ & $27.8 \mathrm{f}$ & $1.76 \mathrm{~b}$ \\
\hline & (W) & $31 \mathrm{~cd}$ & $33.8 \mathrm{fg}$ & $2.10 \mathrm{c}$ & $3.48 \mathrm{~b}$ & $0.18 \mathrm{~d}$ & 37.2 ef & $2.29 \mathrm{~b}$ \\
\hline & (R) & $30 \mathrm{~d}$ & 38.7 efg & $2.08 \mathrm{c}$ & $2.54 \mathrm{~b}$ & $0.13 \mathrm{~d}$ & $41.2 \mathrm{ef}$ & $2.21 \mathrm{~b}$ \\
\hline & (B) & $19 \mathrm{fg}$ & $22.4 \mathrm{~g}$ & $1.58 \mathrm{c}$ & $3.43 \mathrm{~b}$ & $0.18 \mathrm{~d}$ & $25.9 \mathrm{f}$ & $1.76 \mathrm{~b}$ \\
\hline \multirow{4}{*}{250} & (Fl) & $36 \mathrm{~b}$ & $81.2 \mathrm{bc}$ & $5.15 \mathrm{ab}$ & $9.78 \mathrm{a}$ & $0.56 \mathrm{c}$ & $90.3 \mathrm{bc}$ & $5.70 \mathrm{a}$ \\
\hline & (W) & $36 \mathrm{~b}$ & $95.9 \mathrm{~b}$ & $5.81 \mathrm{ab}$ & $10.81 \mathrm{a}$ & $0.64 \mathrm{abc}$ & $106.7 \mathrm{~b}$ & $6.45 \mathrm{a}$ \\
\hline & (R) & $42 \mathrm{a}$ & $125.6 \mathrm{a}$ & $6.55 \mathrm{a}$ & $9.59 \mathrm{a}$ & $0.53 \mathrm{c}$ & $135.2 \mathrm{a}$ & $7.08 \mathrm{a}$ \\
\hline & (B) & $26 \mathrm{de}$ & $75.4 \mathrm{bcd}$ & $6.30 \mathrm{ab}$ & $10.66 \mathrm{a}$ & $0.57 \mathrm{bc}$ & $86.0 \mathrm{bc}$ & $6.87 \mathrm{a}$ \\
\hline \multirow{4}{*}{400} & $(\mathrm{Fl})$ & $35 \mathrm{bc}$ & $56.8 \mathrm{de}$ & $5.36 \mathrm{ab}$ & $11.37 \mathrm{a}$ & $0.83 \mathrm{a}$ & $68.2 \mathrm{~cd}$ & $6.20 \mathrm{a}$ \\
\hline & (W) & $36 a b$ & $73.5 \mathrm{~cd}$ & $6.20 \mathrm{ab}$ & $10.61 \mathrm{a}$ & $0.79 \mathrm{a}$ & $84.1 \mathrm{bc}$ & $6.69 \mathrm{a}$ \\
\hline & (R) & $40 \mathrm{ab}$ & $77.9 \mathrm{bc}$ & $5.86 \mathrm{ab}$ & $10.58 \mathrm{a}$ & $0.76 \mathrm{ab}$ & $88.5 \mathrm{bc}$ & $6.66 \mathrm{a}$ \\
\hline & (B) & $23 \mathrm{ef}$ & $47.8 \mathrm{ef}$ & $4.62 \mathrm{~b}$ & $12.23 \mathrm{a}$ & $0.83 \mathrm{a}$ & $60.1 \mathrm{de}$ & $5.46 \mathrm{a}$ \\
\hline
\end{tabular}

Different letters in the same column correspond to significant differences $(p \leq 0.05)$ by Tukey test.

Concerning light spectra, its effect on plant growth increased with the PPF increasing, being two variables particularly affected: the leaf number, which was negatively affected by the use of B LEDs, and the shoot fresh weight, which was positively affected by the use of R LEDs. Nevertheless, none of these negative and positive effects on plant development had impact on the shoot dry weight, where the significant differences resulted solely from PPF variation.

As it can be seen from figure 2, plants growing under R LEDs presented abnormal leaf development with elongated petioles and pronounced leaf curling. Although visible in all R LED treatments, this effect of leaf curling was reduced with the PPF increase. Also by observation of figure 2, is possible to see that when a non-limiting PPF is 
used, broad spectra provided better results than narrow spectra, by producing plants with higher commercial value. Nevertheless, plants seem to have an enormous capacity to adjust photon receptors to the available wavelengths.

By comparing the two broad spectra used (FL tubes and W LEDs), for all the yield parameters under evaluation (Table 1), W LEDs always presented better results, or at least non-significantly different from those achieved with the use of fluorescent tubes.

Light intensity $\mu \mathrm{mol} \mathrm{m} \mathrm{m}^{-2}$

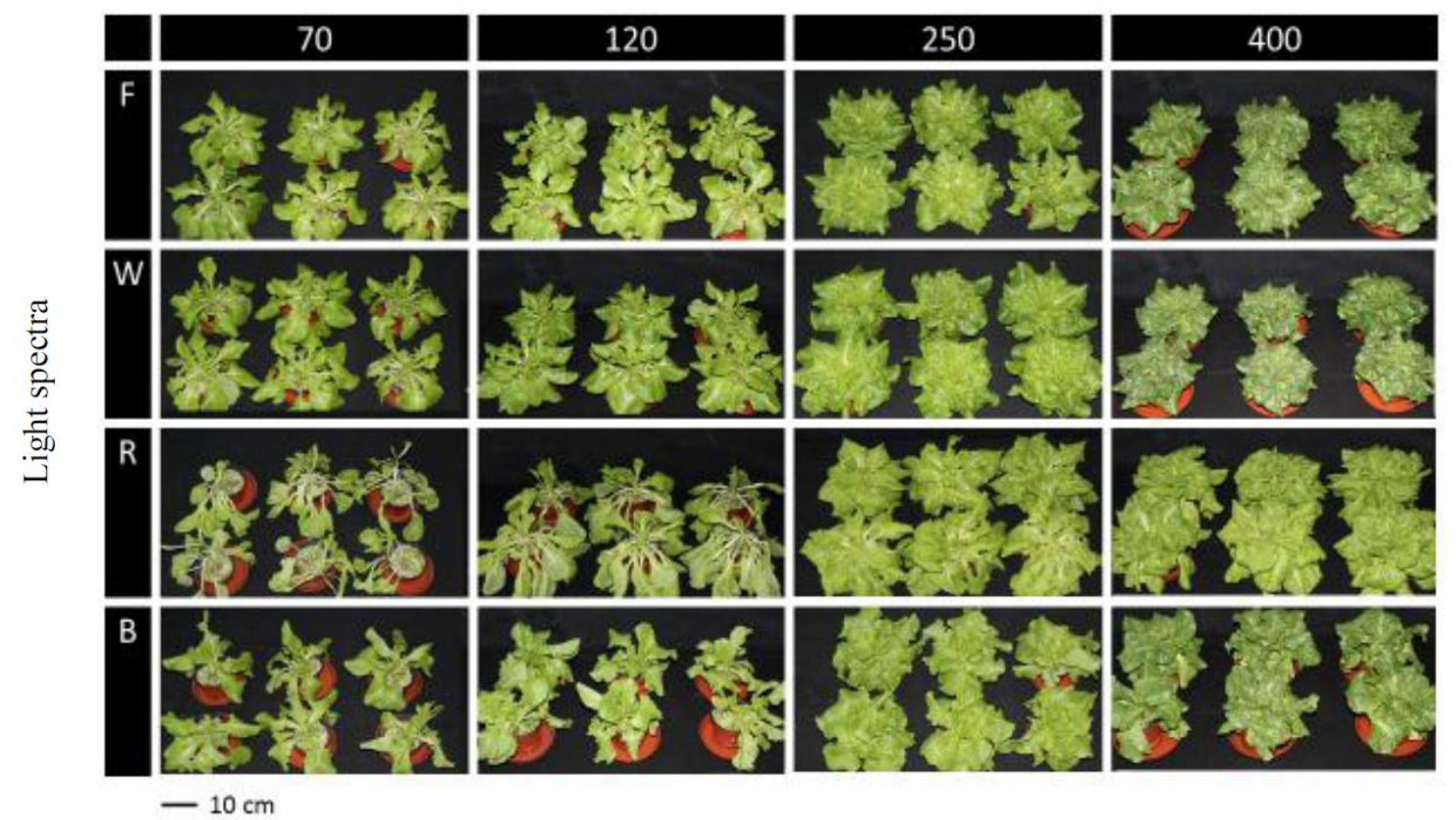

Figure 2. General aspect of plants from the lettuce trial, 40 days after having been transplanted into the four light spectra and the four PPFs tested. On the lowest PPFs, the plants present a non-compact aspect, with elongated petioles and narrow leaves, being those morphological anomalies particularly visible when the R LEDs (R70 and R120) were used. The most compact plants, with the highest commercial value, are those which evolved under a $400 \mu \mathrm{mol} \mathrm{m} \mathrm{m}^{-2} \mathrm{~s}^{-1} \mathrm{PPF}$. Nevertheless, the ones growing under a $250 \mu \mathrm{mol} \mathrm{m}^{-2} \mathrm{~s}^{-1} \mathrm{PPF}$, presented the highest shoot fresh weight

\subsubsection{Trial with Spinach, Turnip and Radish, Under a Single Light Intensity and Four Light Spectra}

The data collected for these three species (dry weight of shoots and roots and leaf number) is presented at table 2. Concerning dry weight, data follows the trend already observed for lettuce on higher PPFs, i.e., no significant differences being registered among spectra, neither for shoot dry weight, nor for total dry weight. For the roots, dry weight presented some differences among spectra, with R LEDs always giving the lowest values, following the same trend already observed for lettuce. 
Table 2. Yield parameters for spinach, turnip and radish

\begin{tabular}{cccccc}
\hline \multirow{2}{*}{ Species } & Light spectra & \multicolumn{4}{c}{ Evaluated Parameters } \\
\cline { 3 - 6 } & & $\begin{array}{c}\text { Shoot dry weight } \\
\text { (g/plant) }\end{array}$ & $\begin{array}{c}\text { Roots dry weight } \\
\text { (g/plant) }\end{array}$ & $\begin{array}{c}\text { Total dry weigh } \\
(\mathbf{g} / \text { plant })\end{array}$ & $\begin{array}{c}\text { Leaf number/plant } \\
(\mathbf{n})\end{array}$ \\
\hline Spinach & (Fl) & $4.06 \mathrm{a}$ & $0.41 \mathrm{~b}$ & $4.47 \mathrm{a}$ & $23 \mathrm{~b}$ \\
& (W) & $5.28 \mathrm{a}$ & $0.44 \mathrm{ab}$ & $5.72 \mathrm{a}$ & $28 \mathrm{a}$ \\
& (R) & $4.44 \mathrm{a}$ & $0.33 \mathrm{~b}$ & $4.77 \mathrm{a}$ & $30 \mathrm{a}$ \\
& (B) & $4.64 \mathrm{a}$ & $0.52 \mathrm{a}$ & $5.16 \mathrm{a}$ & $22 \mathrm{~b}$ \\
\hline Turnip & (Fl) & $4.05 \mathrm{a}$ & $0.62 \mathrm{a}$ & $4.67 \mathrm{a}$ & $10 \mathrm{a}$ \\
& (W) & $5.38 \mathrm{a}$ & $0.75 \mathrm{a}$ & $6.13 \mathrm{a}$ & $10 \mathrm{a}$ \\
& (R) & $5.01 \mathrm{a}$ & $0.55 \mathrm{a}$ & $5.57 \mathrm{a}$ & $11 \mathrm{a}$ \\
& (B) & $5.01 \mathrm{a}$ & $0.56 \mathrm{a}$ & $5.56 \mathrm{a}$ & $8 \mathrm{~b}$ \\
\hline Radish & (Fl) & $1.10 \mathrm{a}$ & $0.85 \mathrm{a}$ & $1.95 \mathrm{a}$ & $7 \mathrm{a}$ \\
& (W) & $1.23 \mathrm{a}$ & $0.70 \mathrm{ab}$ & $1.93 \mathrm{a}$ & $7 \mathrm{a}$ \\
& (R) & $1.32 \mathrm{a}$ & $0.48 \mathrm{~b}$ & $1.80 \mathrm{a}$ & $8 \mathrm{a}$ \\
& (B) & $1.30 \mathrm{a}$ & $0.77 \mathrm{a}$ & $2.07 \mathrm{a}$ & $8 \mathrm{a}$ \\
\hline
\end{tabular}

For each species, different letters in the same column correspond to significant differences $(p \leq 0.05)$ by Tukey test.

Plant species under $340 \mu \mathrm{mol} \mathrm{m} \mathrm{m}^{-2} \mathrm{~s}^{-1} \mathrm{PPF}$

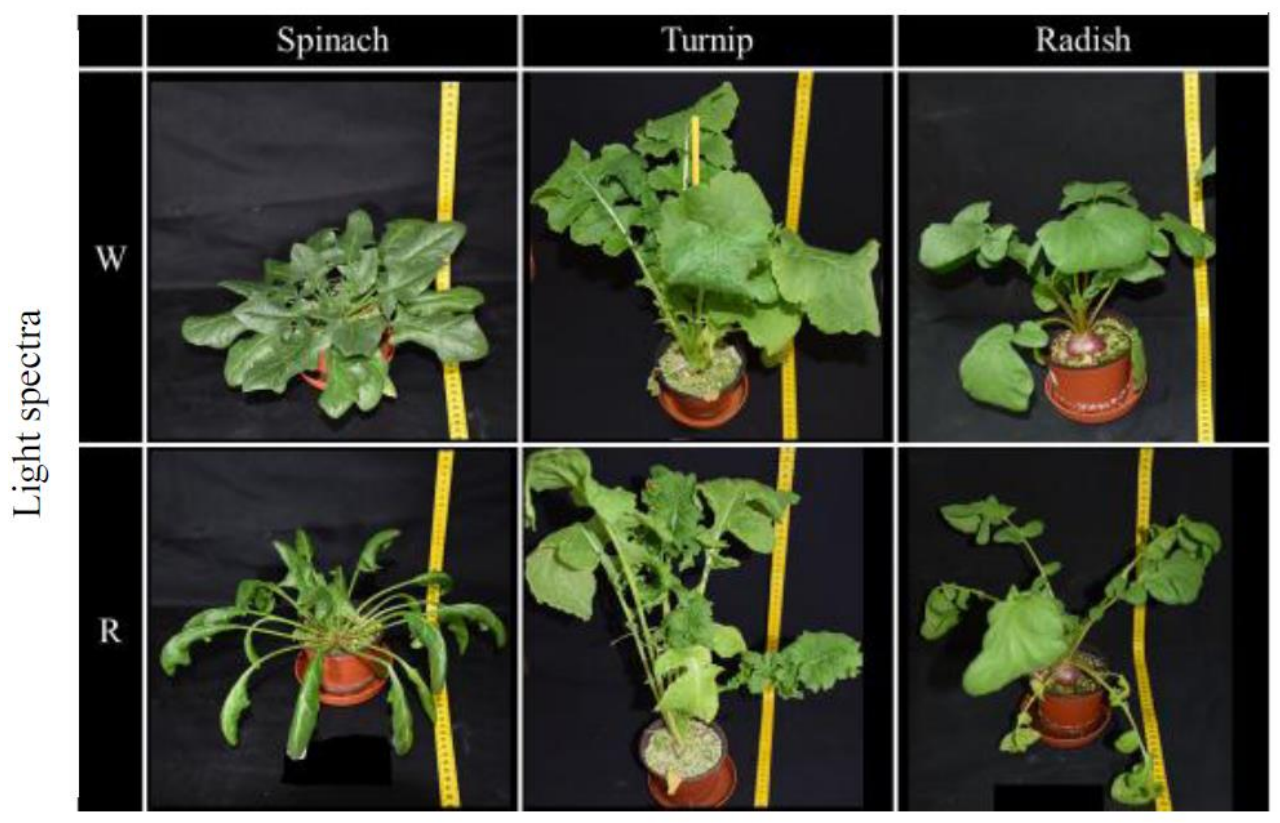

Figure 3. Aspect of spinach, turnip and radish plants growing under R and W LEDs, 40 days after transplant. As registered for the lettuce, the abnormal petiole elongation, as well as the leaf curling, can be observed

Leaf number was also lower when B LED was used. Nevertheless, this effect was not registered for radish, and, with spinach, a reduction on leaf number was also observed with fluorescent light. All plants growing under $\mathrm{R}$ LED light spectrum also presented abnormal leaf development, more pronounced for spinach and radish, as can be seen on figure 3 .

\subsection{Analysis of Physiological Parameters for the Lettuce Trial}

Data related to photosynthetic rate (A), relative chlorophyll content, maximum quantum efficiency of the photochemical center of the active photosystem II (Fv/Fm) and stomatal conductance $(g \mathrm{~s})$, are presented in figure 4. It can be seen that the photosynthetic rate (Figure 4A) increased linearly with PPF increase, but, plants exposed to R LEDs, seem to have achieved maximum net photosynthesis at $250 \mu \mathrm{mol} \mathrm{m}^{-2} \mathrm{~s}^{-1}$. In relation to the light spectra, 
slight differences were observed on photosynthesis for 70, 120 and $250 \mu \mathrm{mol} \mathrm{m}^{-2} \mathrm{~s}^{-1}$ treatments, but, differences became significant, at $400 \mu \mathrm{mol} \mathrm{m} \mathrm{m}^{-2} \mathrm{~s}^{-1}$. At this light intensity, W LEDs performed better than B LEDs $(1,1 \%$ lower), FL (3\% lower) and then R LEDs (4,2\% lower).

Similar evolution patterns were observed for the chlorophyll content. However, for this parameter, on all the PPFs tested, the plants growing under R LEDs presented values of chlorophyll significantly lower than the registered for the other light spectra (Figure 4B).

Concerning the $\mathrm{Fv} / \mathrm{Fm}$ values, is possible to see from figure $4 \mathrm{C}$ that plants plant growing under R LEDs, presented values systematically lower than 0,80 . Also for FL and W LEDs, values lower than 0,8 were registered at $70 \mu \mathrm{mol}$ $\mathrm{m}^{-2} \mathrm{~s}^{-1}$ PPF. The values from stomatal conductance $(g \mathrm{~s})$ are presented in figure 4D. This parameter proved to be highly dependent on the light spectra, with the highest values being always obtained from spectra enriched in blue wavelengths (B and W LEDs). The significant reduction on the $g \mathrm{~s}$ values registered for the $400 \mu \mathrm{mol} \mathrm{m}^{-2} \mathrm{~s}^{-1}$ treatment, were probably conditioned by factors other than the light, as will be discussed below.
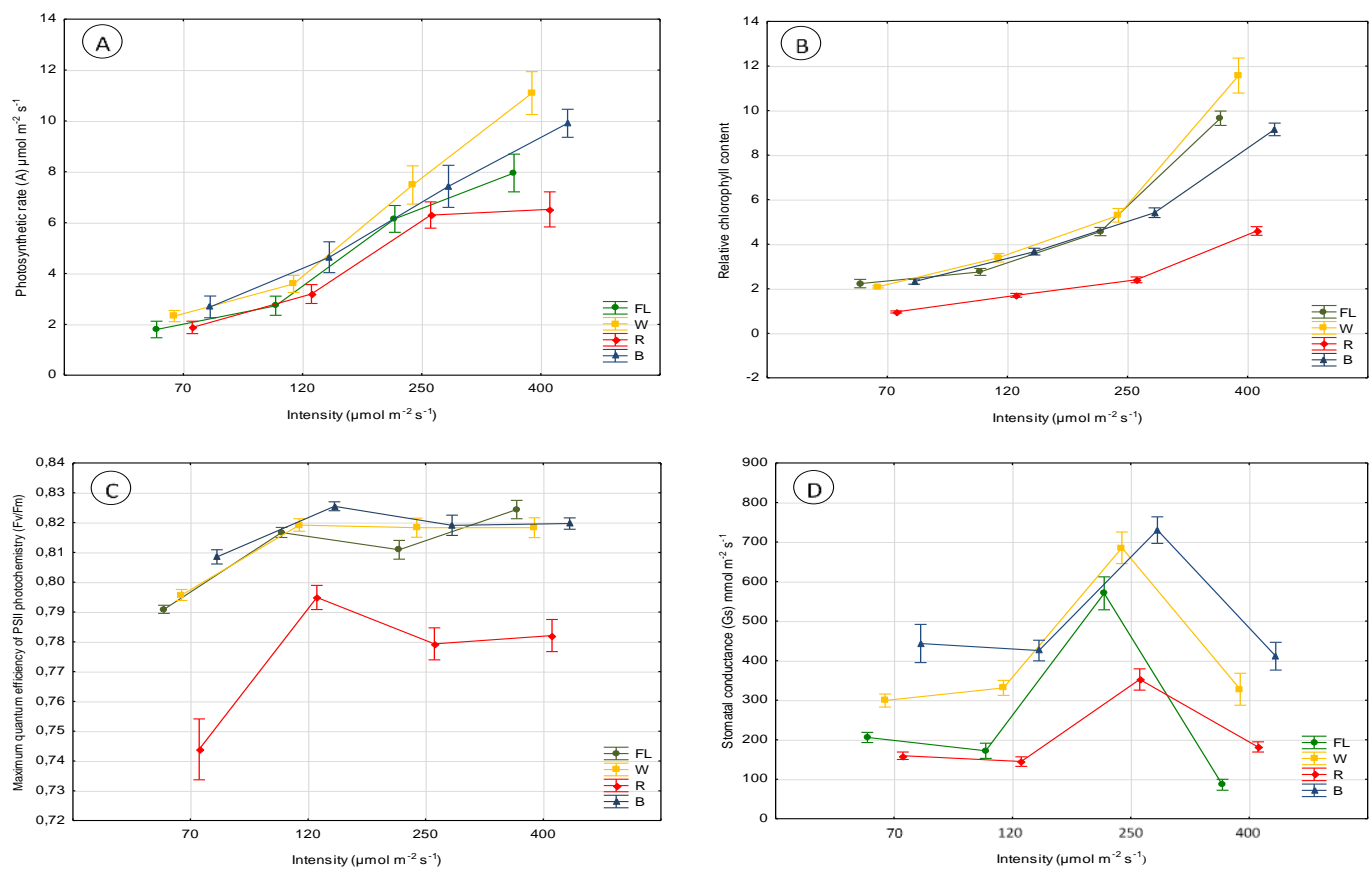

Figure 4. Behaviour of photosynthetic rate (A), relative chlorophyll content (B), maximum quantum efficiency of the photochemical center of the active photosystem II (C) and stomatal conductance (D), on lettuce plants growing under 4 light spectra and 4 light intensity regimes. Bars represent the $95 \%$ confidence intervals

\section{Discussion}

As stated by Snowden, Cope and Bugbee (2016), the effects of spectral quality on plant development are not well understood because much of the current understanding comes from studies where PPFs are usually less than 10\% of the summer sunlight. Moreover, PPFs also change from author to author.

The light saturation point should be one of the most important parameters upon which optimal light intensity regulation is based ( $\mathrm{Fu}, \mathrm{Li} \& \mathrm{Wu}, 2012)$, but, conflicting results are provided by different studies. In lettuce, for instance, some showed that the saturation point is as high as 889 to $932 \mu \mathrm{mol} \mathrm{m}^{-2} \mathrm{~s}^{-1}$ (Knight \& Mitchell $1983 \mathrm{a}$, b), while others point it near 500 to $520 \mu \mathrm{mol} \mathrm{m}^{-2} \mathrm{~s}^{-1}$ (Glenn, Cardran \& Thompson, 1984). This conflicting results on the light saturation point for a species, also do not facilitate PPF regulation in production systems.

From data now presented, it can be seen that significant differences were observed on yield and physiological parameters between the different PPFs used. Nevertheless, for PPFs lower than $250 \mu \mathrm{mol} \mathrm{m}^{-2} \mathrm{~s}^{-1}$, used in lettuce, apart from the leaf number, no other differences related with the spectra were found on the yield parameters, and, in no case, was possible to obtain plants with commercial value. 
The lower leaf number registered when B LEDs were used, is an issue already observed by Chen, Guo, Xue Wang and Qiao (2014) and Wang, Lu, Tong and Yang (2016), and, as confirmed by our trials, seems to be more related with the light spectra than with the PPF levels. As stated by Dougher and Bugbee (2004), blue light induces inhibition of cell expansion and division, which in turn results in fewer internodes and consequently lower leaf number.

The absence of other significant differences on yield parameters, when low PPFs were used, do not agree with the results presented by other researchers working with lettuce in similar conditions. For instance, working at $60 \mu$ mol $\mathrm{m}^{-2} \mathrm{~s}^{-1} \mathrm{PPF}$ intensity, Kobayashi, Amore and Lazaro (2013) reported significant differences in root and total plant dry weight, between fluorescent lamps and monochromatic R or B LEDs. Chen et al. (2014), using $133 \mu \mathrm{mol} \mathrm{m}{ }^{-2}$ $\mathrm{s}^{-1}$, found significant differences in shoot dry weight by comparing growth in $\mathrm{R}, \mathrm{B}, \mathrm{R}+\mathrm{B}$ LEDs and fluorescent lamps. Chen et al. (2016) working with $135 \mu \mathrm{mol} \mathrm{m}^{-2} \mathrm{~s}^{-1}\left(105 \mu \mathrm{mol} \mathrm{m}^{-2} \mathrm{~s}^{-1}\right.$ from W LEDs, supplemented with 30 $\mu \mathrm{mol} \mathrm{m} \mathrm{m}^{-2} \mathrm{~s}^{-1}$ from other LED wavelengths), found significant differences in shoot and root fresh and dry weights.

These differences between ours and other researcher's results, may be related with different trial conditions (temperature, photoperiod, $\mathrm{CO}_{2}$ concentration, plant nutrition) or different plant materials (cultivars), variables already identified by Snowden et al. (2016) as possible sources of variation, which contribute for the difficulty to compare results. It seems that not only PPF standardization is needed, similar actions are also required for other variables.

For treatments where higher PPFs were used $\left(250\right.$ and $400 \mu \mathrm{mol} \mathrm{m}^{-2} \mathrm{~s}^{-1}$ for lettuce and $340 \mu \mathrm{mol} \mathrm{m} \mathrm{m}^{-2} \mathrm{~s}^{-1}$ for the other species), significant differences on yield parameters were already observed among the light spectra tested.

For lettuce, the highest fresh weight was achieved using $250 \mu \mathrm{mol} \mathrm{m}^{-2} \mathrm{~s}^{-1} \mathrm{PPF}$. Nevertheless, these results must be taken with precaution, as we believe that the semi-hydroponic growth system used, may have limited the uptake of water and nutrients by the plants, on situation of maximal request, not allowing the expression of all its full growth potential, when the $400 \mu \mathrm{mol} \mathrm{m}^{-2} \mathrm{~s}^{-1} \mathrm{PPF}$ were used.

In fact, as it can be observed from figure 5, for this PPF and regardless the light spectra, the percentage of water on the leaves $\left(\mathrm{H}_{2} \mathrm{O} \%\right)$ was always significantly lower (3-5\% less), when compared to any other PPF within the same spectrum, meaning that plants were in situation of water deficit on the 400 PPF treatment. The values of stomatal conductance, also being significantly reduced for all spectra, on this transition from 250 to $400 \mu \mathrm{mol} \mathrm{m}^{-}$ ${ }^{2} \mathrm{~s}^{-1} \mathrm{PPF}$, seem to confirm this finding.

In situation of water deficit, the plant tends to close stomata in order to maintain its internal homeostatic equilibrium. So, the higher $\mathrm{H}_{2} \mathrm{O} \%$ on plants illuminated with R LEDs was probably related with the lower stomatal conductance these plants had, which in turn supports the highest values of fresh weight registered for those treatments.

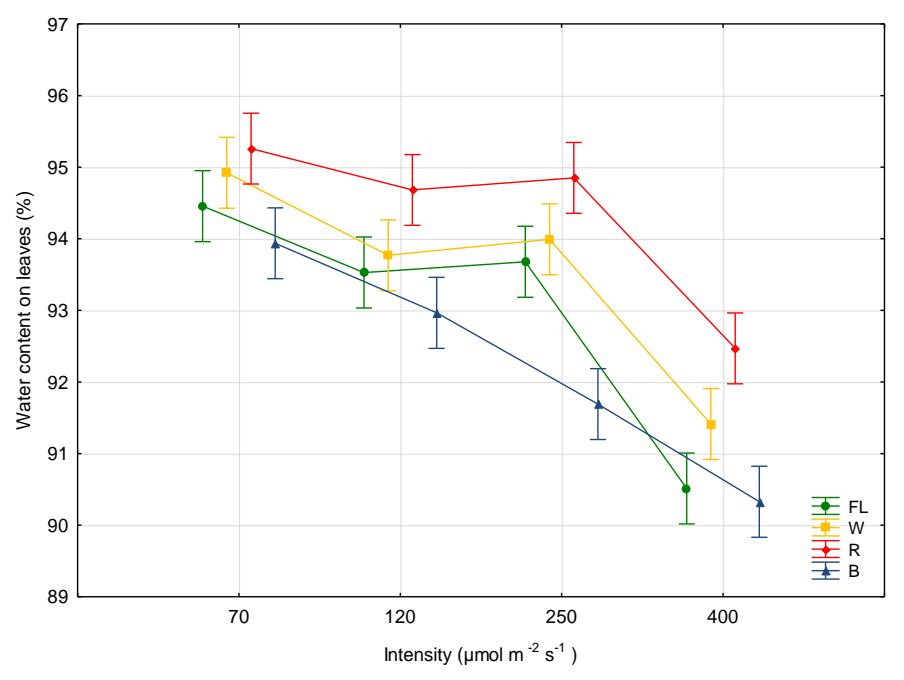

Figure 5. Behaviour of the water content on leaves of lettuce plants, growing under 4 light spectra and 4 light intensity regimes. Bars represent the $95 \%$ confidence intervals 
Also from observation of figure 5, we can see on the B LED treatments a proportional reduction on $\mathrm{H}_{2} \mathrm{O} \%$ for each PPF increase. However, the high values of stomatal conductance registered, linked to a high photosynthetic rate, can justify the nonexistence of differences in the dray weight values among treatments, for each PPF tested.

Is possible to conclude that growth conditions linked to the highest PPF used were limiting plant growth potential, but probably did not encompass a stressful condition as Fv/Fm values bellow 0,8 were only observed for plants growing under R LEDs. The trend towards inadequate values for the $\mathrm{Fv} / \mathrm{Fm}$ parameter in monochromatic R, was also observed by Son and Oh (2013). According to Fu et al. (2012) the relation Fv/Fm reflects the maximal photochemical efficiency of the active center of PSII in the dark. A greater Fv/Fm value results in higher light utilization efficiency and stronger ability of plants to adapt to low-light conditions. Under normal physiological conditions, the Fv/Fm values of the vast majority of $\mathrm{C} 3$ plants are between $0.8-0.84$. When the Fv/Fm value of a plant is below this range, the plant is exposed to some environmental stress, such as drought, low or high temperature, or light stresses.

Concerning photosynthetic rates, those were alaso generally lower when red light was used, although significant differences among spectra only become evident for the highest PPFs. Working with cucumber, Hogewoning (2010), also obtained the lowest values of photosynthesis with monochromatic red. This author refers the existence of a "red light syndrome" associated to lower photosynthetic rates. Low levels of photosynthesis were in fact observed for several species subjected to $100 \%$ red monochromatic light, rice (Matsuda, Ohashi-Kaneko, Fujiwara, Goto, \& Kurata, 2004), wheat (Goins, Yorio, Sanwo, \& Brown, 1997), or radish (Yorio et al., 2001). Wang et al. (2016) also observed lower values of photosynthesis in $100 \%$ red, which were attributed to unresponsive gs and stated that photosynthetic performance of lettuce plants could be efficiently improved by increasing blue light fraction.

In on our trials, apart from the 100\% R LED treatment, for all the other spectra, the photosynthetic rate continued its linear growth trend, observed on each PPF increase, from de lowest to the highest tested (70 to $400 \mu \mathrm{mol} \mathrm{m}^{-2} \mathrm{~s}^{-}$ ${ }^{1}$ ). So, before considering $250 \mu \mathrm{mol} \mathrm{m}^{-2} \mathrm{~s}^{-1}$ as the optimal PPF for lettuce development on controlled environmental growth conditions, data confirmation should be done for plants growing under higher PPFs, using production systems where availability of water and nutrients for the plants can be optimized.

Light intensity also affected significantly the relative chlorophyll content, which presented a growing trend on the four light sources, as light intensity increases. Cope, Snowden and Bugbee (2014), comparing PPFs of 200 and $500 \mu \mathrm{mol} \mathrm{m}{ }^{-2} \mathrm{~s}^{-1}$, also found for lettuce a relative chlorophyll (Chl) concentration consistently higher working with higher PPFs $\left(500 \mu \mathrm{mol} \mathrm{m}^{-2} \mathrm{~s}^{-1}\right)$.

The same authors, working with different proportions of R and B light, reported an increase in Chl content as B light increased from $0 \%$ to about $30 \%$ and then a decrease with $92 \%$ B light. In our experiments, while using $100 \%$ B light, the Chl content increased with the PPF increase, but, for the highest PPF tested, the Chl content was significantly lower for B and R LEDs, when compared with the broad light spectra of FL lamps and W LEDs. As stated by Cope et al. (2014), it seems that Chl synthesis is associated with phytochrome activity, but regulated by a complex interaction of phytochrome and cryptochromes, which is not fully understood.

Borowski et al. (2015) and Wang et al. (2016) observed that higher fractions of Chl in lettuce were achieved with the increasing of B light, and, by the contrary, in monochromatic R, the Chl content was significantly lower. In our trials the Chl content obtained with R LEDs, always presented values significant lower when compared with the other light spectra, inside the same light class intensity. It seems that the absence of blue and green wavelengths, for a given light intensity, significantly affects the content of $\mathrm{Chl}$ in the leaves, being these effect accentuated with the increase in light intensity. In fact, previous work have shown that blue deficiency was adverse to Chl biosynthesis in species like wheat (Tripathy \& Brown, 1995), spinach (Matsuda, Ohashi-Kaneko, Fujiwara \& Kurata, 2008), Rosa $\times$ hybrida (Terfa, Solhaug, Gislerød, Olsen \& Torre, 2013), and cucumber (Hogewoning et al., 2010; Hernández \& Kubota, 2016).

Apart from its specific effect on Chl content, light spectra affected plant development in general, being the most relevant aspect related with the plants growth behavior under W LEDs, with the performance of all species tested, never being inferior to the one achieved with the use of fluorescent tubes. A positive response of the plants to the light produced by W LEDs was already described for instance by Lin et al. (2013). This researchers, working with lettuce, growing under $210 \mu \mathrm{mol} \mathrm{m} \mathrm{m}^{-2} \mathrm{~s}^{-1} \mathrm{PPF}$, compared a mixture of RBW LEDs with a mixture of RB LEDs and verified that the fresh and dry weight of shoots were higher with RBW treatments. The authors assumed that an increase in plant growth with the addition of W light, can be related with its capacity to better penetrate the plant's canopy, providing more light for photosynthesis. Also Zhang et al. (2015), working with lettuce under conditions of commercial plant factory $\left(200 \mu \mathrm{mol} \mathrm{m} \mathrm{m}^{-2} \mathrm{PPF}\right.$ above the canopy and supplementation of basal light at $40 \mu \mathrm{mol}$ $\mathrm{m}^{-2} \mathrm{~s}^{-1}$ ), reported that W LEDs were the most suitable for plant growth, being possible to increase the tradable fresh 
weight and plant quality. This supports the idea that W LEDs can efficiently replace the traditional florescent tubes for plant growth on controlled environment and confirms Mitchell's (2015) thought, when he refers that after a quarter century of testing and development we are in fact rediscovering the value of white light.

But data from our trials also shown that the use of specific narrow wavelengths $(\mathrm{R} / \mathrm{B})$ can be of interest on some situations and that plants can efficiently adapt light receptors to the available wavelengths, in order to survive. In the lettuce trial, for instance, $\mathrm{Fv} / \mathrm{Fm}$ values below 0.8 were registered, indicating somehow that the plants develop under stressful conditions while growing under $100 \%$ red light, but, the highest values of fresh and dray weight were also registered. Son and Oh (2013) also reported the highest fresh weight with the monochromatic R LED treatment, when compared lettuce growing under $100 \% \mathrm{R}$ and different combinations of $\mathrm{R}$ and $\mathrm{B}$ light. Lee and Kim (2013) also working with lettuce and comparing fluorescent lamps with red and blue monochromatic LEDs, verified the same trend, fresh and dry weight increased in $\mathrm{R}$ and decreased in $\mathrm{B}$, when compared to the fluorescent control.

However, morphological changes occurred at the leaf level, which significantly reduced the trade value of the plants. This morphological changes on leaf anatomy, characterized by elongated petioles and leaf curling, is also referred by Massa et al. (2008) or Hogewoning (2010), in situations of plant growth with monochromatic R light.

The absence of B light implies dysfunctions in the photosynthetic apparatus in particular the tissues between the veins. It is referred that an important difference between $\mathrm{R}$ and $\mathrm{B}$ light is the absence of cryptochrome and phototropin stimulation in pure $\mathrm{R}$, whereas pure $\mathrm{B}$ does stimulate cryptochromes, phototropins and also phytochromes. It was conclude that adding a small amount of B light $\left(7 \mu \mathrm{mol} \mathrm{m}^{-2} \mathrm{~s}^{-1}\right)$ these anomalies disappeared, indicating that B light has a quality effect on photosynthetic performance. Ouzounis, Rosenqvist and Ottosen (2015) also refer that plants cannot optimally develop with monochromatic $\mathrm{R}$ light, needing other wavelengths, like B and FR, to regulate other types of responses besides photosynthesis and biomass production.

\section{Conclusions}

LED light opened a new array of possibilities in order to understand plant growth behaviour under narrow band wavelengths, and, most researchers, are still looking for the best combination of R/B/G LED light in order to optimize production. Plants evolved during millions of years under sunlight, possessing different types of photoreceptors which respond to wavelengths from ultraviolet to infrared. Limiting wavelength availability on plant production systems, is in fact to limit the tools developed by the plants for light interception during their evolution. Besides, the use of broad light spectra under photosynthetic active radiation (PAR), has the advantage of reconciling the light needs of plants with the comfort for human vision. Also, the visual diagnosis of symptoms associated with plant nutritional deficiencies, or diseases, are easier to detect with white light than with monochromatic combinations of R/B/G LEDs.

Our results demonstrate that the use of white LEDs, having a broad spectrum that covers the PAR, can be a viable alternative for plant production under controlled environment conditions, efficiently replacing the traditional light sources. Also became evident from acquired data, that light intensity strongly affected plant yield and physiological parameters, being more important for biomass production and photosynthetic performance than light quality emitted by the different light sources. Nevertheless, the lack of standardization of trial parameters among researchers, like the PPFs, still makes difficult to compare results.

\section{Acknowledgments}

This work was partially supported by FEDER funds of the COMPETE program (Programa Operacional Fatores de Competitividade), through the Programa Operacional Regional do Alentejo (InAlentejo), Operation LEDing "Preparando a incorporação da iluminação LED em câmaras climáticas para a cultura de espécies vegetais em ambiente controlado".

\section{References}

Blaauw, O., \& Blaauw-Jansen, G. (1970). The phototropic responses of Avena coleoptiles. Acta Botanica Neerlandica, 19(5), 755-763. https://doi.org/10.1111/j.1438-8677.1970.tb00177.x

Borowski, E., Michalek, S., Rubinowska, K., Hawrylak-Nowak, B., \& Grudzinski, W. (2015). The effects of light quality on photosynthetic parameters and yield of lettuce plants. Acta Scientiarum Polonorum - Hortorum Cultus, 14(5).

Bourget, C. M. (2008). An introduction to light-emitting diodes. HortScience, 43(7), 1944-1946. 
Brandon, M. F., Lu, N., Yamaguchi, T., Takagaki, M., Maruo, T., Kozai, T., .. Yamori, W. (2016). Next Evolution of Agriculture: A Review of Innovations in Plant Factories. In M., Pessarakli (Ed.), Handbook of Photosynthesis, (pp.723-740). Third Edition, CRC Press. https://doi.org/10.1201/b19498-54

Brown, C. S., Schuerger, A. C., \& Sage, J. C. (1995). Growth and photomorphogenesis of pepper plants under red light-emitting diodes with supplemental blue or far-red lighting. Journal of the American Society for Horticultural Science, 120, 808-813.

Cassol, D., De Silva, F. S. P., Falqueto, A. R., \& Bacarin, M. A. (2008). An evaluation of non-destructive methods to estimate total chlorophyll content. Photosynthetica, 46(4), 634-636. https://doi.org/10.1007/s11099-008-0109-6

Chen, X. L., Guo, W. Z., Xue, X. Z., Wang, L. C., \& Qiao, X. J. (2014). Growth and quality responses of 'Green Oak Leaf' lettuce as affected by monochromic or mixed radiation provided by fluorescent lamp (FL) and light-emitting diode (LED). Scientia Horticulturae, 172, 168-175. https://doi.org/10.1016/j.scienta.2014.04.009

Chen, X. L., Xue, X. Z., Guo, W. Z., Wang, L. C., \& Qiao, X. J. (2016). Growth and nutritional properties of lettuce affected by mixed irradiation of white and supplemental light provided by light-emitting diode. Scientia horticulturae, 200, 111-118. https://doi.org/10.1016/j.scienta.2016.01.007

Chia, P. L., \& Kubota, C. (2010). End-of-day far-red light quality and dose requirements for tomato rootstock hypocotyl elongation. HortScience, 45, 1501-1506.

Cope, K. R., Snowden, M. C., \& Bugbee, B. (2014). Photobiological interactions of blue light and photosynthetic photon flux: Effects of monochromatic and broad - spectrum light sources. Photochemistry and photobiology, 90(3), 574-584. https://doi.org/10.1111/php.12233

Cosgrove, D. J. (1981). Rapid suppression of growth by blue light. Plant Physiology, 67, 584-590. https://doi.org/10.1104/pp.67.3.584

Deitzer, G. F., Hayes,R., \& Jabben, M. (1979). Kinetics and time dependence of the effect of far red light on the photoperiodic induction of flowering in Wintex barley. Plant Physiology, 64, 1015-1021. https://doi.org/10.1104/pp.64.6.1015

Dougher, T. A., \& Bugbee, B. (2004). Long-term blue light effects on the histology of lettuce and soybean leaves and stems. Journal of the American Society for Horticultural Science, 129(4), 467-472.

Folta, K. M., \& Carvalho, S. D. (2015). Photoreceptors and control of horticultural plant traits. HortScience, 50(9), 1274-1280.

Fu, W., Li, P., \& Wu, Y. (2012). Effects of different light intensities on chlorophyll fluorescence characteristics and yield in lettuce. Scientia Horticulturae, 135, 45-51. https://doi.org/10.1016/j.scienta.2011.12.004

Glenn E. P., Cardran P., \& Thompson T. L., (1984). Seasonal effects of shading on growth of greenhouse lettuce and spinach. Scientia Horticulturae, 24, 231-239. https://doi.org/10.1016/0304-4238(84)90106-7

Goins, G. D., Yorio, N. C., Sanwo, M. M., \& Brown, C. S. (1997). Photomorphogenesis, photosynthesis, and seed yield of wheat plants grown under red light-emitting diodes (LEDs) with and without supplemental blue lighting. Journal of Experimental Botany, 48(7), 1407-1413. https://doi.org/10.1093/jxb/48.7.1407

Hernández, R., \& Kubota, C. (2016). Physiological responses of cucumber seedlings under different blue and red photon flux ratios using LEDs. Environmental and Experimental Botany, 121, 66-74. https://doi.org/10.1016/j.envexpbot.2015.04.001

Hogewoning S. W. (2010). On the photosynthetic and developmental responses of leaves to the spectral composition of light. (Doctoral dissertation, University of Wageningen, Wageningen, The Netherlands. Retrieved from http://edepot.wur.nl/154537

Johkan, M., Shoji, K., Goto, F., Hashida, S. N., \& Yoshihara, T. (2010). Blue light-emitting diode light irradiation of seedlings improves seedling quality and growth after transplanting in red leaf lettuce. HortScience, 45(12), 1809-1814.

Kang, J. H., KrishnaKumar, S., Atulba, S. L. S., Jeong, B. R., \& Hwang, S. J. (2013). Light intensity and photoperiod influence the growth and development of hydroponically grown leaf lettuce in a closed-type plant factory system. Horticulture, Environment and Biotechnology, 54(6), 501-509.

https://doi.org/10.1007/s13580-013-0109-8 
Kim, H. H., Goins, G. D., Wheeler, R. M., \& Sager, J. C. (2004). Stomatal conductance of lettuce grown under or exposed to different light qualities. Annals of Botany, 94(5), 691-697. https://doi.org/10.1093/aob/mch192

Knight S. L., \& Mitchell C. A. (1983a). Enhancement of lettuce yield by manipulation of light and nitrogen nutrition. HortScience, 108, 750-754.

Knight S. L., \& Mitchell C. A. (1983b). Stimulation of lettuce productivity by manipulation of diurnal temperature and light. HortScience, 18, 462-463.

Kobayashi, K., Amore, T., \& Lazaro, M. (2013). Light-emitting diodes (LEDs) for miniature hydroponic lettuce. Optics and Photonics Journal, 3, 74-77. https://doi.org/10.4236/opj.2013.31012

Kohyama, F., Whitman, C., \& Runkle. E. (2014). Comparing flowering responses of long-day plants under incandescent and two comercial light-emitting diode lamps. HortTechnology, 24, 490-495.

Lee, H. I., \& Kim, Y. H. (2013). Utilization efficiencies of electric energy and photosynthetically active radiation of lettuce grown under red LED, blue LED and fluorescent lamps with different photoperiods. Journal of Biosystems Engineering, 38(4), 279-286. https://doi.org/10.5307/JBE.2013.38.4.279

Lee, S. H., Tewari, R. K., Hahn, E. J., \& Paek, K. Y. (2007). Photon flux density and light quality induced changes in growth, stomatal development, photosynthesis and transpiration of Withania somnifera (L.) Dunal. plantlets. Plant Cell Tissue and Organ Culture, 90, 141-151.

https://doi.org/10.1007/s11240-006-9191-2

Li, H., Tang, C., Xu, Z., Liu. X., \& Han, X. (2012). Effects of different light sources on the growth of non-heading Chinese cabbage (Brassica campestris L.). Journal of Agricultural Science, 4, 262-273. https://doi.org/10.5539/jas.v4n4p262

Li, Q., \& Kubota, C. (2009). Effects of supplemental light quality on growth and phytochemicals of baby leaf lettuce. Environmental and Experimental Botany, 63, 232-239. https://doi.org/10.1016/j.envexpbot.2009.06.011

Lian, M. L., Murthy, H. N., \& Paek, K. Y. (2002). Effects of light emitting diodes (LED) on the in vitro induction and growth of bulblets of Lilium oriental hybrid 'Pesaro'. Scientia Horticulturae, 94, 365-370. https://doi.org/10.1016/S0304-4238(01)00385-5

Lin, K. H., Huang, M. Y., Huang, W. D., Hsu, M. H., Yang, Z. W., \& Yang, C. M. (2013). The effects of red, blue, and white light-emitting diodes on the growth, development, and edible quality of hydroponically grown lettuce (Lactuca sativa L. var. capitata). Scientia Horticulturae, 150, 86-91. https://doi.org/10.1016/j.scienta.2012.10.002

Lu, N., Maruo, T., Johkan, M., Hohjo, M., Tsukagoshi, S., Ito, Y., ... Shinohara, Y. (2012). Effects of supplemental lighting with light-emitting diodes (LEDs) on tomato yield and quality of single-truss tomato plants grown at high planting density. Environmental Control in Biology, 50, 63-74. https://doi.org/10.2525/ecb.50.63

Massa, G. D., Emmerich, J. C., Morrow, R. C., Bourget, C. M., \& Mitchell, C. A. (2006). Plant-growth lighting for space life support: a review. Gravitational and Space Research, 19, 19-29.

Massa, G. D., Kim, H. H., Wheeler, R. M., \& Mitchell, C. A. (2008). Plant productivity in response to LED lighting. HortScience, 43(7), 1951-1956.

Matsuda, R., Ohashi-Kaneko, K., Fujiwara, K., \& Kurata, K. (2008). Effects of blue light deficiency on acclimation of light energy partitioning in PSII and $\mathrm{CO} 2$ assimilation capacity to high irradiance in spinach leaves. Plant and Cell Physiology, 49(4), 664-670. https://doi.org/10.1093/pcp/pcn041

Matsuda, R., Ohashi-Kaneko, K., Fujiwara, K., Goto, E., \& Kurata, K. (2004). Photosynthetic characteristics of rice leaves grown under red light with or without supplemental blue light. Plant \& Cell Physiology, 45(12), 1870-1874. https://doi.org/10.1093/pcp/pch203

Maxwell, K., \& Johnson, G. N. (2000). Chlorophyll fluorescence - a practical guide. Journal of experimental Botany, 51(345), 659-668. https://doi.org/10.1093/jexbot/51.345.659

McCree, K. J. (1971). The action spectrum absorptance and quantum yield of photosynthesis in crop plants. Agricultural Meteorology, 9, 191-216. https://doi.org/10.1016/0002-1571(71)90022-7

Mitchell, C. A. (2015). Academic research perspective of LEDs for the horticulture industry. HortScience, 50(9), 1293-1296. 
Morrow, R. C., \& Tibbitts, T. W. (1988). Evidence for involvement of phytochrome in tumor development on plants. Plant Physiology, 88(4), 1110-1114. https://doi.org/10.1104/pp.88.4.1110

Okamoto, K., Yanagi, T., \& Kondo, S. (1997). Growth and morphogenesis of lettuce seedlings raised under different combinations of red and blue light. Acta Horticulturae, 435, 149-157. https://doi.org/10.17660/ActaHortic.1997.435.14

Ouzounis, T., Rosenqvist, E., \& Ottosen, C. O. (2015). Spectral effects of artificial light on plant physiology and secondary metabolism: a review. HortScience, 50(8), 1128-1135.

Pimputkar, S., Speck, J. S., DenBaars, S. P., \& Nakamura, S. (2009). Prospects for LED lighting. Nature Photonics, 3, 180-182. https://doi.org/10.1038/nphoton.2009.3

Samuolienè, G., Brazaitytė, A., Sirtautas, R., Viršilè, A., Sakalauskaitè, J., Sakalauskienė, S., ... Duchovskis, P. (2013). LED illumination affects bioactive compounds in romaine baby leaf lettuce. Journal of the Science of Food and Agriculture, 93(13), 3286-3291. https://doi.org/10.1002/jsfa.6173

Schwartz, A., \& Zeiger. E. (1984). Metabolic energy for stomatal opening: Roles of photophosphorylation and oxidative phosphorylation. Planta, 161, 129-136. https://doi.org/10.1007/BF00395472

Shin, K. S., Murthy, H.N., Heo, J. W., Hahn, E. J., \& Peak, K. Y. (2008). The effect of light quality on the growth and development of in vitro cultured Doritaenopsis plants. Acta Physiologiae Plantarum, 30, 339-343. https://doi.org/10.1007/s11738-007-0128-0

Snowden, M. C., Cope, K. R., \& Bugbee, B. (2016). Sensitivity of seven diverse species to blue and green light: Interactions with photon flux. PloS One, 11(10), https://doi.org/10.1371/journal.pone.0163121

Son, K. H., \& Oh, M. M. (2013). Leaf shape, growth, and antioxidant phenolic compounds of two lettuce cultivars grown under various combinations of blue and red light-emitting diodes. HortScience, 48 (8), 988-995.

Terfa, M. T., Solhaug, K. A., Gislerød, H. R., Olsen, J. E., \& Torre, S. (2013). A high proportion of blue light increases the photosynthesis capacity and leaf formation rate of Rosax hybrida but does not affect time to flower opening. Physiologia Plantarum, 148(1), 146-159. https://doi.org/10.1111/j.1399-3054.2012.01698.x

Tripathy, B. C., \& Brown, C. S. (1995). Root-shoot interaction in the greening of wheat seedlings grown under red light. Plant Physiology, 107 (2), 407-411. https://doi.org/10.1104/pp.107.2.407

Wang, J., Lu, W., Tong, Y., \& Yang, Q. (2016). Leaf morphology, photosynthetic performance, chlorophyll fluorescence, stomatal development of lettuce (Lactuca sativa L.) exposed to different ratios of red light to blue light. Frontiers in Plant Science, 7, 250. http://doi.org/10.3389/fpls.2016.00250

Wojciechowska, R., Kołton, A., Długosz-Grochowska, O., Żupnik, M., \& Grzesiak, W. (2013). The effect of LED lighting on photosynthetic parameters and weight of lamb's lettuce (Valerianella locusta). Folia Horticulturae, 25(1), 41-47._https://doi.org/10.2478/fhort-2013-0005

Wright, M. (2016, September 20). Science advances in matching LED lighting to horticultural needs. LEDs Magazine, pp. 47-53.

Yorio, N. C., Goins, G. D., Kagie, H. R., Wheeler, R. M., \& Sager, J. C. (2001). Improving spinach, radish, and lettuce growth under red light-emitting diodes (LEDs) with blue light supplementation. HortScience, 36(2), 380-383.

Zeiger, E., \& Zhu, J. (1998). Role of zeaxanthin in blue light photoreception and the modulation of light-CO2 interactions in guard cells. Journal of Experimental Botany, 49(Special Issue), 433-442. https://doi.org/10.1093/jxb/49.Special_Issue.433

Zhang, G., Shen, S., Takagaki, M., Kozai, T., \& Yamori, W. (2015). Supplemental Upward Lighting from Underneath to Obtain Higher Marketable Lettuce (Lactuca sativa) Leaf Fresh Weight by Retarding Senescence of Outer Leaves. Frontiers in Plant Science 6 (1110). https://doi.org/10.3389/fpls.2015.01110

Zhou, Y. H., Zhang, Y. Y., Zhao, X., Yu, H. J., Shi, K., \& Yu, J. Q. (2009). Impact of light variation on development of photoprotection, antioxidants, and nutritional value in Lactuca sativa L. Journal of Agricultural and Food Chemistry, 57(12), 5494-5500. http://pubs.acs.org/doi/abs/10.1021/jf8040325 


\section{Copyrights}

Copyright for this article is retained by the author(s), with first publication rights granted to the journal.

This is an open-access article distributed under the terms and conditions of the Creative Commons Attribution license (http://creativecommons.org/licenses/by/4.0/). 